\title{
COLLECTIVE HUMAN RESURRECTION IN MODERN SECULAR FANTASTIC AND SPECULATIVE FICTION: AN OVERVIEW
}

\author{
Mariano Martín RodRíGUEZ \\ mariano.martin@ec.europa.eu
}

Recibido: 09-08-2017

Aceptado: 24-06-2018

(c) (1)

\begin{abstract}
It would be a complete «revolution» (etymologically a turn-around) if death were defeated and the deceased returned to the world as they were, in the flesh and with their own individuality, instead of coming back as reanimated monsters. This fantastic possibility is usually described as having revolutionary existencial and societal effects, since the society and the emotional lives of the living is usually transformed through the contact with the returned, whose very presence seems to alter the meaning of life. This paper provides an overview of resurrection stories by international writers, from Giacomo Leopardi to some modern classics, such as Tudor Arghezi, Érico Veríssimo, Marcel Thiry, Angélica Gorodischer and Robert Silverberg, as well as by others less well known, in a variety of fictional works on this matter, especially in the fantastic, but also in the speculative mode.
\end{abstract}

KeYWORDS: collective resurrection, fantastic fiction, speculative fiction, English literatures, Romance literatures. 
INTRODUCTION

The word «revolution» ultimately derives from Latin revolutio, which is the noun corresponding to the verb revolvo. This means more or less to «roll over» or «turn back». Unlike its customary political meaning, «revolution» does not mean, etymologically, an epochal change of political regime, social mores or public mentality. It is, rather, a turning back to a real or imagined past. With this in mind, some writers have conjured up a revolution that would mean a complete turnaround of our existential condition as beings fated to die sooner that most of us would like. Through this revolution, the deceased would collectively ${ }^{1}$ return to life, instead of turning living people into dead ones, as most political revolutions in the world from 1789 onwards have all too often endeavoured to do. The consequences which this return of the dead as resurrected human beings would entail, both for their families and society at large, have been examined in a series of literary fictional works ${ }^{2}$ that we address in this general, comparative and descriptive overview. ${ }^{3}$

First of all, it is necessary to clearly distinguish these works from the staggering amount of fiction dedicated to re-animated corpses. We are considering here only the dead ones returned in their own flesh, sometimes with just some physical or mental changes as a result of the passage through death. We are not considering corpses coming back as reanimated monsters, such as mummies and zombies, ${ }^{4}$ whether sentient or not. Humans resurrected as

1 There are literary fictions where an individual, famous (William Shakespeare, Miguel de Cervantes...) or not, real or fictional (for instance, Don Quixote has often been resurrected), divine (Jesus of Nazareth has fictionally returned a few times well before the awaited official Second Coming) or human, returns in a later age, usually for the author to satirically compare present and past times. Being an exceptional occurrence, this individual returns do not have the public dimension needed in utopian fiction.

2 The collective return of the formerly dead as human beings has been shown in a few movies and television series, such as Robin Campillo's film Les Revenants (2004) and its television spin-off (Les Revenants, 2012, 2015), and the TV series Resurrection (2014). Since I am not familiar with the semiotics of audio-visual products, I have thought preferable not to consider them in this survey.

3 This overview is just a first description of the full corpus of fictions focusing in collective resurrection that I have been able to find in order to propose a very broad taxonomy. This could allow future scholars to have at their disposal accurate descriptions of a whole series of relevant works on which to apply deeper theoretical approaches to the matter following, for example, Foucaultian insights on biopolitics. 4 Both cannibal zombies, as they are portrayed in most contemporary fiction, and zombie slaves devoid of will according to traditional Haitian beliefs and some Western science fiction, such as Michael Swanwick's short story «The Dead» (1996; reissued as a play in Moondogs, 2000), where the deceased are brought back through technological means in order to constitute a docile workforce for capitalism able to replace all flesh. They are just endowed with the limited intellectual skills necessary to perform their jobs, without any trace of their former personality. This is why they are zombies rather than resurrected beings according to our definition. Nevertheless, this story aptly addresses the issue of the redundant nature of a great majority of human living beings in a system that wishes to reduce labour costs to near zero, while the workforce can be exploited as fully as robots. The resurrected zombies are shown here as fully obedient and able to outperform humans in every physical task, from boxing to sexual intercourse. 
digital copies of deceased ones according to transhumanist ideologies are not considered here, either. Furthermore, since our main objective is to review how the living and their society (which is, after all, our own as not-dead-yet humans) are confronted with the return of the very ones that had long departed, we are also excluding any fictions where the resurrected are on their own in another material place, such as the Riverworld planet imagined by Philip José Farmer in a series of novels and short stories. Although the apocalyptic myth survives in some of these fictions, their approach must be secular to be considered here.

Last but not least, we are limiting our survey to works written in English or any Romance language. Unfortunaltely, I will have to leave aside works as interesting as Shinichi Hoshi's millennial story translated from Japanese into German as «Der Zeitwirbel». ${ }^{5}$ It still encompasses a substantial number of works, among which some narratives in different languages that are considered significant in their respective literatures, as well as others also considered as such in the narrower semiosphere of fantastic and speculative literature. Nevertheless, our intent is not to consider these works as primarily artistic textual artifacts, but to explore them as cultural descriptions of speculative kinds of new societal situations following the usually unexplained and, therefore, fantastic resurrection of a more or less wide group of deceased people in the modern period, this is to say, after the French revolution of 1789 and its secularising influence on politics, society and culture. These works offer various answers to some questions that could arise following such occurrence in a world endowed with limited resources, both material and emotional.

\section{The Philosophical and Symbolical Approach}

Before becoming a social issue to be addressed in the world of the living, collective resurrection had been subjected to philosophical musings in modern fiction. Death is also a metaphysical state that can be endowed with

5 In Hoshi (1982: 82-100). This short story describes a secular millennium of unknown causes: it is fully impossible to do any forecasts from a given date in the near future; upon reaching this date, it turns out to be a perfect day, with everybody idling in the pleasant weather, feeling good and expecting an unknown final event. The day ends with no event, but it is soon discovered that every day repeats the same pleasant final day, except for the fact that the dead begin returning, each one in the reversed anniversary of his or her death. This allows for everyone to come to terms with any unfinished emotional business, to forgive and to be forgiven, to find bliss. Since every consumed resource is recovered intact the following day, the resurrection event has no impact on material well-being. Hoshi's world is fully utopian, whereas resurrection is addressed solely from an emotional and ethical perspective. 
symbolic value. In Giacomo Leopardi's «Dialogo di Federico Ruysch e delle sue mummie» (Operette morali, 1827), ${ }^{6}$ the fifteen-minute resurrection of the corpses resting in that scientist's laboratory, as well as in the whole world, allows them to sing an hymn about their state: death is not only painless, but it is rather pleasant («Piuttosto piacere che altro»; Leopardi, 1976: 196) since it liberates individuals from life's sorrows and pain. Understandably, the dead are not especially interested in regaining their former lives, although their very short resurrection has a metaphysical purpose: to collectively sing the same poem stating «la solida realtà del nulla che circonda quel 'punto acerbo', che é la nostra esistenza» (Bertilaccio, 2008: 52):

Sono i morti che chiamano i vivi, qui; è la morte che irrumpe (non evocata, ma agente di sua propria forma per virtù dell' «anno grande e matematico») che squarcia l'involucro razionale e rassicurante di quella che chiamamo «vita» (2008: 52).

Leopardi's clearly pessimistic stance can be seen time and again among later authors regarding the convenience of death; for instance, in Clark Ashton Smith's «The Empire of the Necromancers» (1932; Lost Worlds, 1944), the long-dead summoned by a couple of wizards to serve them, as they would serve their monarchs in a royal court, succeed, thanks to their former king's agency to go back to «the last, ultimate nothingness,» which appears to be their desired place of rest, whereas the necromancers must wander in «life-indeath» (Smith, 2006: 170) with no peace. It is interesting to observe how the dead are seen in Leopardi's seminal text, as well as in Smith's, as a community of humans who have left behind human feelings, becoming an emotionally different species, with whom communication is rather difficult. Furthermore, death seems to level former differences: Leopardi's shortly returned seem a truly unified community able to act unanimously. In his «moral little work», their action is poetic (they sing one of Leopardi's lyrical masterpieces) and fully neutral regarding humans, whose fate in life is no concern of theirs.

In further symbolical treatments of the collective resurrection matter, the coming back to life may serve a cosmic purpose: the triumph of common good upon social evil. For instance, in the story by Venezuelan author Luis López Méndez, «La balada de los muertos» (1892), written in the mode of

6 The dates between brackets following the title of a literary work are here always those of the first edition. The editions used for this paper are described in the final section of quoted works. 
fantastic Romanticism, ${ }^{7}$ the dead rise from their allegorical city to advance towards that of the living, whose inhabitants are mute and without will, being subjected to a human moral monster who has enslaved them within and without. The dead voice their common desire of using the divine harmony known in death to build up a utopian city of truth and justice. They are prevented, however, by a young race of lively and vigorous men («hombres lozanos y vigorosos»; López Méndez, 2000: 182) who will build up that future city instead of them. These new men respectfully conduct the resurrected dead back to the cemetery, since their supernatural purpose has been taken over by the living, who are the truly responsible for Earth's condition. This hopeful conclusion constrasts with the pessimism about the ability of the living ones to create a fairer world order in several fictions also borrowing the image of the dead coming out from their tombs in John's Revelation. For instance, Ursicin G. G. Derungs' "Il sault dils vivs» (1978; Il cavalut verd ed auter, 1988) is a «dance of the living» (as the Romansh title means), where the resurrected return to show the failure of the established church to abide by its own teachings. ${ }^{8}$ Although it all appears to be a verger's nightmare, the city of God on Earth is mercilessly satirised from the perspective of Liberation Theology. Accordingly, a Christian utopia is nevertheless implied as a potential alternative even before the apocalyptical millenium.

A further secular derivation of the last book of the New Testament does not offer such a clear prospect, but its open ending may convey a sense of hope that would correct its very pessimistic outlook on the society of the living. In Tudor Arghezi's novel Cimitirul Buna-Vestire (1936), a somehow naive and well-meaning intellectual is presented as a victim of manevuring and corruption among local politicians: in spite of his doctoral qualifications, he is designated only surveyor of the Good Tidings Cemetery in Bucharest; there, he is one of the first to witness the progressive rise of the dead from their graves and their return to the city, where they are rather badly received. Supported by the church authorities, the Government puts them on trial as impostors (their hearts do not beat, so they cannot be the true persons who had long passed away). Even national eminences such as the Romanian national

\footnotetext{
7 «[L]a pieza revela una decidida voluntad de manejo de los códigos literarios del Romanticismo fantástico» (Sandoval, 2000: 77).

8 In a commentary on his own tale, Derungs states that the resurrected are a metaphor for the unconscious drives «killed» by the traditional Catholic Church. These allegedly «dead» drives wish «clamar en memoria ch'ellas vivan e che nus, mortificond ellas per viver, essan daventai mascras cu entagls fatschas» [to cry out in the memory that they live and that, by mortifying them in order to live, we have become masks instead of having faces] (1978: 258).
} 
poet Mihai Eminescu are judged. Jesus Christ himself is prosecuted. This full reversal of the Revelation myth underlines the hellish nature of «living» society by presenting a cosmic disturbance (it is soon discovered that the return of the dead coincides with the suppression of death; nobody can die anymore) that becomes the opposite myth to the Biblical one of creation:

Acea acţiune decreatore, acea perturbaţie cosmică pe care o produce misterioasă răsculare a morţilor [...] devine inversul genezei, reprezentarea unei demonii negatoare, ce nu permite nicio istorie, niciun trecut ori un viitor. (Balotă, 1979: 317) [That de-creative action, that cosmic disturbance that produces the mysterious revolt of the dead (...) becomes the reverse of Genesis, the representation of a negative denial that does not allow any history, neither past nor future.]

By prosecuting Jesus, the religious solution seems to have been excluded, leaving nothing but the desire for salvation, expressed through a final song of praise to God, a God that is, however, apparently absent. Only hope remains, along with the very same mystery of the defeat of death. Arghezi's masterfully written novel points out a supernatural way out of human corruption, but denies us any clearly consolatory solution, as well as any utopian possibility on Earth or elsewhere that would compensate for the dire views of grotesque evil obsessively pervasive in Arghezi's narrative.

The double approach, both satirical and ultimately transcendental, adopted by this Romanian modern classic is split in further fictions of the returned. The satirical dimension is prevalent in the long novel by Érico Veríssimo entitled Incidente em Antares (1971). This was soon received as a literary protest against the military regime ruling Brazil back then, as well as a brilliant example of Latin American magical realism. In this novel, which reads for most of its pages as a realist portrayal of the unequal and unjust social conditions prevailing in a Southern Brazilian town, a fantastic element is introduced that seems to subvert the realistic approach, but which finally underlines the documentary nature of the narrative, which seems to be intended as a symbolical portrayal of a real political regime, the latest military dictatorship ruling Brazil back then. That fantastic ingredient is the request by seven recently deceased to be buried during a general strike. Since this is unfeasible due to this strike, they go to the city and pressure Antares' officials to address the strikers' concerns. In the process, since they are dead and are, therefore, not subjected to social decorum, they can speak up their minds about their fellow citizens and even about their own greedy families. This introduces a carnivalesque dimension: the strike and the seven suspended dead mark a 
time of exception, when former hierarchies and social and political stereotypes can be put publicly into question. The dead express a necessary social criticism: «Symbolically speaking, social change must occur before the past can be properly buried in Antares. In this sense, as they wait for the sun to rise before setting out in the city, the defuntos embody the hope of a new socio-economic order in Antares (Moser, 2008: 237)».

Unfortunately, the return of the still-rotting dead is what puts an end to the strike. The strikers themselves make sure that they are properly buried, while the city's authorities also succeed in covering up the «incident». Therefore, their brief resurrection does not bring about any meaningful change; it only reveals the extent to which both the living and the returning dead are more or less willingly subjected to a corrupted social order: ${ }^{9}$

Temos ressaltado o fato de os mortos ocuparem um lugar provisório de que a decomposição de seus corpos é um índice significativo e o desequilíbrio criado por eles mostrar-se por isso como passageiro. Embora esse desequilibrio acelere os conflitos que se mostram no «espetáculo dos mortos», também assegura a continuidade do equilíbrio; en suma, a resurreição dos mortos é um acontecimento que já traz consigo as marcas de sua curta duração (Soares Fonseca, 2005: 37-38).

In Antares, injustice goes, and will go, hand in hand with corruption, as it happens in Arghezi's fictional world. However, in Veríssimo's work, a transcendental, supernatural solution to the moral shortcomings of living humankind is excluded, perhaps due to the fact that the deceased, unlike Arghezi's returned, have recovered their former personalities and status, even if their being now living corpses allows them to voice criticisms usually repressed among the city's inhabitants.

A similar approach to collective resurrection can be appreciated in a later Spanish novel, Antonio Menchaca's Resucitar en Palermo (1990). For unknown reasons, the mummies resting in the catacombs of the Capuchins in the Sicilian capital gradually return to life, exactly as they were when they passed away. After the initial confusion both among them and among the church and secular authorities, they all come to terms with their new existence in different

9 Also in Latin America, there is a further example of resurrection fiction rooted in local historical circumstances, but where the deceased fully reverse their former views on politics. In Gabriel Saldías Rossel's «Santiago del Correcto Extremo» (Fricciones, 2016), Víctor Jara and other victims of Augusto Pinochet's repression are the only ones returned among the living today, but they happen to worship the memory of their executioner, since he has secured them this second life. Apart from the irony of the situation, this tale does not raise any questions regarding the philosophical and social status of the returned. In this, this story can be seen as related to Veríssimo's novel. 
ways. They are treated as well or as badly as other refugees are in Italy and other European countries in contemporary times. Some of them can integrate into modern Italian society, some even cynically exploiting to their advantage the malfunctions of it. Others follow a resurrected monk, who had revolted in the interior of the isle against the state, and secure for themselves, thanks to guerrilla tactics and the fact that they are invulnerable to wounds, a territory where they try to create on Earth the Kingdom of God for the poor preached by liberation theologians. Although they succeed at first, they are doomed. Since it is proven that they can be definitely killed by beheading, the earthly authorities ask for the assistance of the mafia to suppress the rebellion, because mafiosi will not be stopped by human rights issues. Indeed, they soon put an end to this utopia by beheading its leader. This had become ineffectual following his inner conflict between social justice and happiness on Earth, and his religious conviction that these goods are only being really possible in paradise, in the afterlife. This is metaphorically underlined by the fact that all the dead mysteriously return to their place of rest as mummies in the catacombs of the Capuchins following the monk's Christ-like sacrifice. As it happened in Antares' piece, their revival in Palermo was only a temporary break in the social and metaphysical order. The mystery of death and resurrection is not unveiled and the resurrected are finally unable to bring to civilisation any improvements inspired by their extraordinary perspective following their direct experience of dead and of the passage of historical time. They were still too similar to the living in their passions and senses. Utopia requires perhaps an ethically superior humankind, as the one embodied by the resurrected in Marcel Thiry's novelette «Le concerto pour Anne Queur» (1949; Nouvelles du grand possible, 1960), where they are truly different from the living.

Unlike the unexplained resurrections surveyed so far, Thiry frames his rich symbology in the context of reasoned imagination. This is underlined by his choice of a historiographical mode of writing:

L'écrivain utilise divers procédés de narration communément employés dans les livres d'histoire (...) il raconte des faits lointains, avec toute l'objectivité de l'historien sans visages qui a interrogé le passé et collecté patiemment notes et témoignages pour servir la vérité. (Hallin-Bertin, 1981: 132-133)

Moreover, resurrection does not appear here as a mysterious, fantastic or magical occurrence. It is explained through an anticipated scientific and technical innovation. This warrants the classification of this story as science fiction, as a fully secular and materialist approach to our subject matter. 
Nevertheless, the Christian subtext is almost as powerful as in Arghezi's novel, the main difference between them being that Arghezi's Christian (reversed) eschatology is replaced by Christian ethics in Thiry's work. Dr Cham, the Congolese inventor of a procedure to give new life to the deceased, limits the procedure to a small number of qualified persons according to their extraordinary artistic and intellectual skills, but above else according to their high ethical virtues and spirituality (not necessarily confessional, though). Anne Queur is one exception to this rule, since she is an unexceptional young woman, prematurely deceased. The resurrected are called the «dry» ones, due to the fact that their new body is almost devoid of flesh. They are still material, but also as close as possible to being spirits. Dr Cham's purpose was, indeed, to bring through them the kingdom of the Spirit on Earth. Unburdened by the passions of the flesh, their intelligence connects all of them through telepathic links until they become a single intelligence intent on bringing about Truth and Purity. This agenda is not readily accepted by the fleshed living humans, who try to suppress the dry ones, though their attempt fails. In contrast, the returned can very well eliminate the «Flesh», but Anne Queur convinces them to sacrifice themselves instead. This tragically underlines their high ethical standards, which are obvious throughout the story, as well as their Christian messianic dimension. By sparing the fleshed humans, however, they also prevent the coming of the utopia of a world without the lies, the crimes and all the evils of «normal» living humans. Unlike too many revolutionaries willing to kill millions in order to bring about their alleged utopias, the dry ones finally discover that life is precious, thanks to the touching character of the young woman serving as bridge between both communities and symbolising both the beauties and flaws of our world as opposed to the perfection of utopia, whether spiritual or not. Perfection is not for the living. The returned cannot save us, because they are not us anymore.

This idea, which can be deducted from Thiry's narrative, is brought to full fruition in a couple of further science fiction stories illustrating the unbridgeable chasm brought about by the experience of death, even if the latter is overcome. Even love itself is powerless. In Lisa Tuttle's «The Hollow Man» (1979; A Spaceship Built of Stone and Other Stories, 1987), a woman resorts to a procedure to resurrect people in order to bring back her husband, who had killed himself, only to see that he did not wish to be brought back. As in most other cases, the returned are fully unable to feel any emotion; they just keep living after their resurrection. This situation is, of course, most unsatisfactory for the loved ones who wanted them back, and this seems to be why the pro- 
cedure is not widely used: as Leopardi would have it, they are happier dead than living, and so are their families.

Lisa Tuttle just reinforces the Leopardian stance already present in Robert Silverberg's masterful novelette «Born with the Dead» (1974). ${ }^{10}$ With an outstanding sense of psychological expression in the mode of High Modernist masters, whose lessons Silverberg seems to have unobtrusively assimilated, the narrative shows how the obsession to retrieve the lost ones can be troubling for oneself and for the whole society. In its fictional world, resurrection is technically possible and it is sometimes performed, but has also brought about the appearance of a community of returned fully separated from that of the living. Although they are not as physically different as Thiry's dry ones, the returned in Silverberg's work also seem to share, for unexplained reasons, a superior form of mental communication that allows them to connect with each other far better than the living can among themselves. They also seem devoid of human passions, fully indifferent to what moves the living. In order to avoid undesired contact with these, the returned live in their own cities, which are forbidden to the non-resurrected. These cities of the formerly dead are described by Silverberg as quite similar to usual American towns, albeit with a lack of passions among their inhabitants and, therefore, of violence. The main character can see it when he sneaks into one of them after his deceased wife, now a returnee and obviously not interested in meeting him again. He keeps chasing her all over the world, until even the returned, usually rather patient and civil, can take it no more and kill him in order to resurrect him. He then discovers that, in fact, the returned do not share the feelings of the living: he will never try to see his ex-deceased wife again; he is now alone, but also free. Death cleanses out human psychological and emotional weaknesses. At the same time, it makes us inhuman if we believe that feelings and passions, including those that make us fail morally, are also a valuable part of ourselves, a contention that much of the symbolical resurrection fiction surveyed so far seems to contest by insisting on the essential otherness of the returned. As such, they are as unable to respond to our needs as we are to theirs.

Mariana Enríquez explores this essential otherness of the dead returned in the framework of a dysfunctional society, as well as its possible symbolic causes, in her short novel Chicos que vuelven (2011). The tale, narrated from the

10 Silverberg reissued this novelette in 2013 in a volume along with a sequel written by Damien Broderick entitled «Quicken». This sequel tries, and fails, to describe the feelings of the resurrected main character as a returned individual, before sending him on an outer space journey in order to explain, in rather confusing terms, the scientific logic of the resurrection through quantum mechanics, as well as through a poorly justified cosmic plan. 
perspective of a female employee of the office for enquiring about missing persons in Buenos Aires, shows in a colloquial and effective idiom how children and teenagers who have escaped home, especially due to their indifferent or even abusive families, face a dire fate as prostitutes and/or drug addicts and dealers, thus easily falling prey to modern society's ills. These victims reappear gradually in the city (the extraordinary unexplained occurrence is limited to the Argentinean capital), are next rescued by public institutions and often welcomed back by their families. However, these «returning children» are not the same young people that had disappeared. They retain their former personality and memories, but they do not have bodily needs, and they look emotionally empty. Their families become afraid of them and send them back to public institutions, which do not really know what to do with them. Although the living hide it under pretences of civilisation, they are, in fact, frightened by the very existence of the returned children. The issue is finally solved by these children, who meet in an abandoned house before leaving together for an unknown destination as a sort of herd or collective organism. Their leaving can be read as having a symbolic value: these children are excluded beings both when alive and when resurrected, tragically demonstrating the double failure of family and society. In a slightly later novel written in the best American tradition of Sherwood Anderson, Jason Mott's The Returned (2013), this failure is expanded to the whole world, and not just to an Argentina slowly recovering from the traumatic experience of the state-induced disappearance of thousands of men, women and children during the Military Junta's dictatorship.

Mott's narrative, set in a small town in the Southern United States, deals with healing the wounds inflicted on our souls by the final departure of our loved ones, and with the difficult acceptance of such departure. Again for unexplained reasons, long dead people start appearing far from their homes as if time had not passed since their deaths, but remembering nothing of their having passed away. One of them is an eight-year-old child who is brought back to his parents, who are now old. Although they know that he cannot be their true child, they treat him as if he were, as they do to other neighbours, also returned. They consider the returned as fellow human beings, whereas many other people reject them, even violently, as if they were impossible monsters. The child's parents also oppose the government's policy of detaining the returned in concentration camps, one of which is set in their own town. At the end, all the returned disappear as mysteriously as they had appeared, after having allowed some of the people experience recovery through 
«memory and love» (Mott, 2013: 338), while many others had kept their hearts locked. Unconsciously, the returned had offered a utopia of love recovered, thanks to the suspension of their otherness. They had come to us as vulnerable individuals, not as a distinct and powerful community. Nonetheless, they cannot be readily admitted in the city of the living. Love would not suffice when material considerations entered the equation. Mott's novel combines, indeed, the philosophical issue of the status of the returned, the main concern in the fictions surveyed so far, with the social one entailed by the challenge of including back in the community the ones that had departed from it for ever. For the American and other governments dealing with a surge of old/new citizens to cater for, the main concern was not love or spirit, but how to prevent the collapse of social order under the pressure of a population that was, and was not, alien. In The Returned, the answer is detention camps. Other options have also been explored in fiction, as we will presently see.

\section{THE SOCIAL APPROACH}

The mixed reaction to collective resurrection in Mott's The Returned follows a long tradition of fictional antipathy towards collective resurrection as a social, rather than emotional phenomenon. This resistance runs parallel to the one to be seen in the linked topic of immortality. ${ }^{11}$ Individually, one might wish for immortality as much as one could desire the return of the deceased loved ones, but as a member of society, the prospect would probably not be a rosy one. Collective immortality would impose excessive pressure on our planet, while the return of the dead in great numbers would tear society apart for a variety of reasons. These are already comically sketched in a one-act play in (nearly doggerel) verse premiered in Madrid in 1878, Eduardo Zamora y Caballero's Enmendar la plana a Dios. When it is known that a pharmacist has scientifically concocted a potion able to resurrect the dead and that he is going to test its effects in the local cemetery, he is pressed to give up his plans first by a woman little interested in seeing her late husband again, then by a physician alarmed by the prospect of losing his patrons since nobody will be afraid of dying and, finally, by relatives of a deceased captain concerned by his returning to claim his money, now shared by their heirs. At the end, a crowd threatens the inventor until he agrees with them that God takes whom

11 See, for example, Guthke (2015). This survey on collective resurrection in literary fiction follows a comparative and culturally historical method similar to the one used in that German study. 
He likes, and there should be no interference with His work, although religious reasons are rather secondary in this play.

This preference for the dead to remain in their graves is shared by further Hispanic writers, even without religious overtones. This negative view of any natural or supernatural novum giving rise to secular resurrection might be attributed to a certain mistrust of historical novelties and «revolutions' that have often resulted in conditions far worse than the previous ones; we could also blame a widespread trend that sees the potential negative consequences and abuses of any human progress, a stance that we can considerer either pessimistic or lucid. On the other hand, this pessimism is often balanced by humour. Although the issue can be examined in all seriousness, the comic tone helps readers to swallow the bitter pill of a rather black view of society and mankind as these are confronted, as a whole, with issues of life and death.

As a successful literarily example of this, a short story by Angélica Gorodischer entitled «La lucha de la familia González por un mundo mejor», collected in the volume entitled Trafalgar (1979), should/could be mentioned. In this narrative, the universal and continuous resurrection of the deceased is shown as the main source of oppression for the living. The question of limited food and work resources is not directly discussed there, since the returned keep existing without bodily needs. Rather, the oppressive nature of a past always physically present and preventing any new initiative causes the unhappiness of those forced to cohabit with the resurrected ancestors following a celestial recurrent phenomenon. This consists in a comet's mysterious gases turning the dead immediately into reanimated corpses, but who nevertheless keep their personalities intact and are able to talk and move normally. The narrator of this story is Trafalgar, an Argentinian anti-hero telling to (silent) friends, in the typical style of club stories and familiar conversation, his travels to different far-fetched planets in order to trade. He arrives on this one only to see that everybody has the same surname «González» (all of the inhabitants are aware of being related thanks to the living testimony of the returned), that technology is forbidden and that people are afraid of opposing their many ancestors, intent on controlling the behaviour of their living descendants, spouses, etc., The formerly dead also wish to prevent the living from introducing any novelty contrary to old habits and from enjoying the sensual pleasures now precluded to them, as reanimated people are unable to enjoy any pleasures of the flesh. As a result, progress can hardly take place in any form, although there are resistant groups of «Bad Children» («Malos Hijos;» Gorodischer, 1979: 141) who secretly develop technology and try to keep in touch with the Earthling-like inhabitants of other planets. 
Trafalgar succeeds in helping the bad children by getting assistance from a technologically advanced alien culture to block the comet's gases that had prevented the dead from following the common course of corpses. Thus, life and civilisation can then follow theirs in González's world. This happy end, which is consistent with the pleasant light comedic tone of the story (and of Trafalgar as a whole), does not mean that the author is pulling punches. Not only are the resurrected a starkly conservative force in itself, they also had succeeded, through their sheer number and their unity of intent, in making true life miserable, as well as in rooting out open opposition. The living are mostly conditioned to accept resignation and conformity; even their authorities are chosen depending on their docility to the rule of the dead, while the progressive bad children have to work in secret and without real hope of overturning them until alien technology comes to the rescue, thanks to Trafalgar, as a Deus ex Machina saviour from another planet. The González could not find enough forces within their civilisation to withstand the conservatism underpinned by the resurrected, who are in a stronger position to shape their society as it better suits them, having been around for longer and since earlier.

A similar kind of world is presented in a fantastic short story by Luis García Jambrina, entitled «Overbooking» (Muertos S.A., 2005), which complements Gorodischer's approach with an examination of the speculative economic and work-related impact of collective resurrection on contemporary societies, especially in a Europe continuously facing a lack of sufficient financial resources to satisfy ever-increasing social demands. A rather ineffectual young man discovers one morning that a woman is using his bathroom. She tells him that the afterlife is now so full that many have been sent back to life, to their former homes. Trying to avoid a property conflict, he goes out for a walk in the city. It seems more populated than earlier: the queues in front of public administration institutions, such as employment offices, are longer than usual, since the formerly dead also wish to get their social benefits back. Back home, after considering the possibility of sharing his apartment with the attractive returned woman, he sees that her husband has also returned from an undescribed afterlife. The young man leaves his apartment for good, clueless about what to do. The open ending prevents us from knowing if the other living are going to react in the same passive way, but the story raises nonetheless the issue of a large and sudden influx of aliens having to (re)integrate into any given society, when this is not ready to receive them, unless the natives are excluded from their limited pool of resources (housing, etc.). García Jambrina's narrative can be read as a metaphorical comment on the unintended 
consequences of the welfare state, as well as of the dire fate of those in it, such as the unemployed youth, that are not in a position to challenge their elders who enjoy vested rights, and who certainly are the most interested in keeping any liberalisation and change at bay. The reversal of death would entail the suspension of social renewal, a «revolution» to prevent «evolution» and to return to things past, in order to keep them as they were: as static as they are in traditionally-minded utopias, both in books and in practice, and whenever this social stasis is promoted, either in an Arcadian past, in an egalitarian communist future, or in an idealised welfare present.

These Spanish-language resurrection fictions are hardly conservative in substance, although their pessimism regarding the possibility of including the resurrected in the society of the living in a fair manner could also be read as a sign for a general sense of mistrust regarding e modernity and globalisation often found in nations feeling themselves on the losing side of contemporary historical development. A more optimistic outlook on the matter can be appreciated, for instance, in French and Anglo-American resurrection stories focusing on the social consequences of such a fantastic development. For instance, Bernard Quiriny adopts in «D'outre-tombe» (Une collection très particulière, 2012) a humoristic tone when he narrates, using the historiographical discourse, how recently deceased people begin to come back among the living with their full personality. This rationally unexplained return requires some adjustments, both administrative (for instance, are the returned entitled to their former properties and rights?) and psychologic (nobody is afraid of taking risks knowing that there will be a second normal existence, but life looks absurd without the prospect of final death). Society seems, however, to have come to terms with this extraordinary occurrence in a pragmatic manner, and with rather positive results for most people, who can afford now to be easy-going with regard to their (first) biological end.

This optimism is usually not fully shared by English language writers exploring the possibility of technologically induced resurrection. Nevertheless, unlike Hispanic writers appearing to be wary of novelty for novelty's sake, Anglo-American speculative fiction writers often embrace technology even if proven morally and socially questionable when dealing with the fictional subject here surveyed. Probably, the hegemonic status of English-speaking countries in the world, primarily of the United States of America, has persuaded writers from these countries that technical progress is not to be curtailed, especially if it is promoted by the huge corporations working together with their governments to advance the geopolitical interests of the lat- 
ter ones, through their so-called soft power, or otherwise. Accordingly, a farfetched idea such as collective resurrection is taken for granted as long as it appears to be technically viable, without any apparent resistance from the public administration or civil society until it is too late. First innovate and then think of the consequences is the idea underpinning most of the works in English on the matter. This is probably not the right place to discuss whether this reflects or not real-life situations and ideologies, although the difference from the Hispanic approach, as described above, seems clear.

In the above-mentioned Spanish early resurrection play, a socially risky technology is finally abandoned following a consideration of its potential effects. In contrast, Robert Silverberg had addressed the possibility of being technologically Recalled to Life (1958; reissued with changes in 1972) and endorsed it enthusiastically. The novel's hero is James Harker, a former American presidential candidate and prominent lawyer who agrees to publicly defend a new technology for resurrecting recently dead people through a complicated process entailing the risk of reanimating just the body, but leaving its mind blank. When the news of the discovery is leaked, he chooses to fight for it through preventive legislation against a public outcry by religious and conservative groups, changing public opinion and ethical doubts about the procedure. He overcomes all of them by sheer will and even accepts to die and to be resurrected in order to prove that this is a viable technology, once the «zombie' risk is effectively addressed. Harker finally overcomes all opposition; he can now look forward to the new task ahead in a world where death has been defeated. He knows that «[t]he hardest part is yet to come», but he believes that «it's all going to turn out for the best» (Silverberg, 1975: 188) in the core tradition of American imperial (and golden age science fiction) optimism proper to the land of promise and dreams fulfilled, at least in theory.

Silverberg himself would later show how it turned «out for the best' in the above-commented novelette «Born with the Dead». By then the era of the unquestioning celebration of technology was over. From New Wave science fiction and, especially, cyberpunk onwards, the old optimism was partly replaced by the awareness of the dangers of any uncontrolled technology within the capitalist system. Their warnings, however, usually end up becoming the endorsement of what we are being warned against through the perhaps illusory perception that saviour-heroes can arise from within the very system being criticised in order to set things right. A happy end is thus secured, while the relevant technology, risky or not, is finally endorsed as well. This can be clearly perceived in a couple of novels on a new class divide brought about by 
the same kind of technology promoted in Silverberg's Recalled to Life, albeit with the changes requested by the contemporary development of information technologies. Both in Kevin J. Anderson's Resurrection, Inc. (1988; reissued with changes in 2012) and Ian McDonald's starkly cyberpunk Necroville (1994; alternative title: Terminal Café), all kinds of electronic devices incorporated into the resurrected allow for their enhancement, or their debasement, according to the policies paid, or not, for their voluntary, or forced, resurrection. A minority of wealthy people (corporate tycoons in Anderson's novel, computer geniuses and other Postmodernist stars in MacDonald's) enjoy the system to the full, even to the extent of wanting to die and be resurrected out of ennui in Necroville. They have no scruples about using the cheap labour composed of the formerly dead, whose own memories and will are limited to the minimum necessary to keep them properly performing their appointed tasks, from manual to sexual, while living workers become redundant and social discontent must be repressed by force (in Resurrection, Inc.) or other more devious means (in Necroville). Fortunately, a hero among the wealthy and powerful experiences a process that makes him (it is, of course, a male in both cases) reconsider his position in society, as well as the fairness of it all, especially after he risks being de-classed due to conspiracies within their privileged classes. In their fight for survival, both heroes discover that there is an underground movement of resurrected servants who had been able to overcome their electronic implants in Anderson's story, or that have built up a civilisation off the planet from which they can defend their brethren on Earth in McDonald's. In one way or another, the heroes are at the centre of a counter-conspiracy in favour of a fairer balance of power between both kinds of humankind in worlds where information technologies are so extensively used that the traditional definition of human as a natural animal no longer applies, and the boundaries between life and death, between mechanical and organic, are blurred. In this context, resurrection is just a part of a whole technological package that these two writers never really question. Confronted with the dystopian worlds resulting from the unchecked exploitation of technological progress by the American type of full free market capitalism, they depict the uneasy coexistence between the living and the resurrected in credibly dark tones, but they avoid any fundamental criticism as they show how the system can help itself, not through collective action, but mostly through individual agency. The system is rotten but its operation is restored, after some improvements, by the providential hero. Readers can relax: the good guy cannot but prevail, and dystopia will be soon corrected, but not reversed. No need to give 
up collective resurrection, because someone will eventually save the day, sparing us the need to consider if the whole thing had been properly conceived in the first place. If something wrong happens with American-style capitalism and the technology going along with it, we do not need to worry. They will ultimately bring us utopia and life everlasting, whatever the costs. This consolatory prospect is usual in commercial thrillers coming from that cultural area, as well as in those written globally to compete with them in the book market. Anderson's and McDonald's novels are written according to this formula, although McDonald tries harder to conceal it under postmodernist, or rather late modernist, rhetorical and structural devices adding to the overall confusion in the plot without much improving his writing, following the fashion of his time. In contrast, Resurrection Inc. is honestly written in the conventional novelistic mode usual in science fiction, without particular literary pretention, as one more fish in a very densely populated pond.

\section{Conclusion}

Considering their limited literary ambition, it is perhaps out of place to ask for a serious reflection on the effects of speculative collective resurrection within a given society in commercial fiction basically intended for unproblematic reading. There are certainly some hints in the right direction, but the formulaic novels in English on resurrection from a social perspective, and the too short and light pieces in Spanish in the same vein, do not go much further beyond that. Jason Mott could have addressed this issue more deeply in The Returned, but his main objective was probably to explore the existential dimension of such an occurrence, following others that have done the same also in a literarily apt manner, from Giacomo Leopardi to Robert Silverberg. The sublime emotion arising from the cosmic prospective of an eternity of life or, alternatively, the liberating laughter of carnivalesque humour arising from the image of corpses as puppets adopting the masks of life have often taken the centre stage. Therefore, the ominous social and psychological dimension of collective resurrection has usually given, in my opinion, better literary results in the fantastic than in science fiction. Maybe loss is too intimate a reality for us to adopt an estranged perspective and to consider mainly the social dimension of death overturned as a potential source of a new order that could be objectively presented and reflected on. Therefore, collective resurrection has seemingly found a more congenial literary space within fantastic fiction, 
although this matter offers perspectives so encompassing that it has inspired science fiction and magical realist writers as well. The «revolution' of death overcome, the truest of all, could not be expressed but in a variety of fictional ways while we wait for it to become, naturally or supernaturally, actual. Until then, it can only be an imaginary prospect or, if you wish, fantastic literature. ${ }^{12}$

\section{BIBLIOGRAPHY}

Anderson, Kevin J. (1998): Resurrection Inc., Harper Collins, London.

ArgheZI, Tudor (1983): Cimitirul Buna-Vestire (ed. Mariana Ionescu), Minerva, București. Balotă, Nicolae (1979): Opera lui Tudor Arghezi, Eminescu, București.

Bertilaccio, Roberto (2008): «Sulla soglia. Il Coro di morti del Dialogo di Federico Ruysch e delle sue mummie», Per Leggere, 14, pp. 41-58.

BoccI, Simone (2013): L'uomo dell'oltrevita, Viola, Roma.

BRODERICK, Damien (2013): «Quicken», in Robert Silverberg and Damien Broderick, Beyond the Door of Death, Phoenix Pick, Rockville, pp. 91-182.

Derungs, Ursicin G. G. (1978): «Il sault dils vivs - Enzacons patratgs», in Litteratura: Novas Litteraras, 1, 2, pp. 257-261.

Derungs, Ursicin G. G. (1988): «Il sault dils vivs», in Il cavalut verd ed auter, Porclas, Milano, pp. 145-150.

Enríquez, Mariana (2010): Chicos que vuelven, Eduvim, Villa María.

García Jambrina, Luis (2005): «Overbooking», in Muertos S.A., El Gaviero, Almería, pp. 71-74.

Gorodischer, Angélica (1979): «La lucha de la familia González por una vida mejor», in Trafalgar, El Cid, Buenos Aires, pp. 123-154.

GuTHKE, Karl S. (2015): Lebenszeit ohne Ende: Kulturgeschichte eines Gedankenexperiment in der Literatur, Köngigshausen und Neumann, Würzburg.

Hallin-Bertin, Dominique (1981): Le Fantastique dans l'œuvre en prose de Marcel Thiry, Palais des Académies, Bruxelles.

HoshI, Shinichi (1982): «Der Zeitwirbel», in Sfaus Japan: «Die Hand des kosmischen Affen» und 9 weitere Geschichten (eds. Ken Okura, Wilfert Peter, Werner Zillig), Wilhelm Goldmann, München, pp. 82-100.

Leopardi, Giacomo (1976): «Dialogo di Federico Ruysch e le sue mummie,» in Operette morali (ed. Saverio Orlando), Rizzoli, Milano, pp. 191-197.

López MéNDEZ, Luis (2000): «La balada de los muertos», in Días de espantos (cuentos fantásticos venezolanos del siglo XIX) (ed. Carlos Sandoval), Universidad Central de Venezuela, Caracas, pp. 177-182.

12 Part of this paper was presented at the Royal Colloquium «Utopia and Revolution», in Sinaia (Romania), 22-25 June 2017. The full paper was written within the framework of the research project HAR2015-65957-P under the Spanish R \& D \& I National Plan. I thank Sara Martín and Álvaro Piñero for having helped me to improve the language and the contents of this paper. 
McDonald, Ian (1994): Necroville, Victor Gollancz, London.

MenchacA, Antonio (1990): Resucitar en Palermo, Siruela, Madrid.

Moser, Robert H. (2008): Carnivalesque Defunto: Death and the Dead in Modern Brazilian Literature, Ohio University Press, Athens.

Mотт, Jason (2013): The Returned, Harlequin MIRA, Richmond.

QuiRINY, Bernard (2012): «D'outre-tombe», in Une collection très particulière, Seuil, Paris, pp. 23-31.

SaldíAs Rossel, Gabriel (2016): «Santiago del Correcto Extremo», in Fricciones, Nadar, Santiago de Chile, pp. 9-11.

Sandoval, Carlos (2000): El cuento fantástico venezolano en el siglo XIX, Universidad Central de Venezuela, Caracas.

Silverberg, Robert (1975): Recalled to Life, Panther Books, St Albans.

SilverberG, Robert (1977): «Born with the Dead», in Born with the Dead, London, Coronet Books, pp. 5-87.

Sмiтh, Clark Ashton (2006): «The Empire of the Necromancers», in Lost Worlds (ed. Jeff Vandermeer), University of Nebraska Press, Lincoln - London, pp. 159-170.

SoARES FonseCA, Maria Nazareth (2005): «Incidente em Antares e os paradoxos da arte de representar», O Eixo e a Roda: Revista de Literatura Brasileira, 11, pp. 25-41. $<$ https: / / doi.org/10.17851/2358-9787.11.0.25-41>

Swanwick, Michael (2005): «The Dead», in The Best of the Best: 20 years of The Year's Best Science Fiction (ed. Garden Dozois), St. Martin's Griffin, New York, pp. 342-351.

THIRY, Marcel (1987): «Le Concerto pour Anne Queur», in Nouvelles du grand possible (ed. Pascal Durand), Labor, Bruxelles, pp. 195-274.

Tuttle, Lisa (1987): «The Hollow Man», in A Spaceship Built of Stone and Other Stories, The Women's Press, London, pp. 135-164.

Veríssimo, Érico (1978): Incidente em Antares, Globo, Rio de Janeiro.

ZAMORA y CABAlLERO, Eduardo (1878): Enmendar la plana a Dios (pasillo inverosímil con ribetes de filosófico, en un acto y en verso), Hijos de A. Gullón, Madrid. 